\author{
V. Usov ${ }^{1}$, N. Shkatulyak ${ }^{1}$, O. Savchuk ${ }^{2}$, N. Rybak ${ }^{1}$
}

\title{
Kearns Texture Parameters, Mechanical Properties and Damageability of Titanium Sheet after Alternating Bending
}

\author{
${ }^{\text {I} S o u t h ~ U k r a i n i a n ~ N a t i o n a l ~ P e d a g o g i c a l ~ U n i v e r s i t y ~ n a m e d ~ a f t e r ~ K . D . ~ U s h i n s k y, ~ O d e s s a, ~ U k r a i n e, ~ v a l e n t i n u s o v 67 @ ~ g m a i l . c o m ~}$ \\ ${ }^{2}$ National University "Odessa Maritime Academy", Odessa, Ukraine, z9816@yandex.ua
}

\begin{abstract}
This work aims to determine the Kearns texture parameters and evaluate on their basis the elastic moduli, mechanical properties (ultimate tensile strength, conditional yield stress), as well as damageability parameters of the sheets commercial titanium (CT-grade 1: $0.04 \% \mathrm{Fe} ; 0.015 \% \mathrm{C} ; 0.05 \% \mathrm{~N} 0.05 \% \mathrm{c} ; 0.009 \% \mathrm{H}$ ) as delivered after rolling and annealing at $840{ }^{\circ} \mathrm{C}$ (original sheet) and further alternating bending $(\mathrm{AB})$ in the amount of $0.5 ; 1$, 3 and 5 cycles. Damageability parameters characterizing damage accumulation were determined from the elastic modulus change after the above-mentioned number of $\mathrm{AB}$ cycles relative to the values of the elastic modulus in different directions of the original sheet of the studied titanium. The elastic constants of the single crystal and the Kearns texture parameters were used to estimate the elastic modulus in the rolling direction (RD) and transverse direction (TD) of the original sheet, and sheets after an above number of AB cycles. The deviation of the calculated and experimental values of the elastic modulus did not exceed $5 \%$. The deviation of the calculated and experimental values of the ultimate tensile strength and yield stress in the RD and TD both in the initial state and after the corresponding number cycles of the $\mathrm{AB}$ did not exceed $10 \%$.
\end{abstract}

Keywords: Kearns texture parameters, elastic modulus, ultimate tensile strength, conditional yield stress, damageability.

Received 10 May 2021; Accepted 25 August 2021.

\section{Introduction}

The wide use of titanium and its alloys in aviation and rocketry is due to its relatively low density and high specific strength. The hexagonal crystal structure of polycrystalline titanium grains contributes to the development of anisotropy of semi-finished products due to the formation of a crystallographic texture during processing. The anisotropy of semi-finished products can limit the practical use of titanium and its alloys, increasing the amount of scrap in products (for example, the formation of festoons during stamping).

However, texture can not only serve as a source of waste in products. The creation of a certain texture in a metal material can significantly increase the strength of products. For example, the creation of a favorable texture in the VT5-1 titanium alloy makes it possible to increase the deformation resistance under biaxial tension by $45 \%$ in comparison with the uniaxial one [1].
Most modern sheet metal processing technologies involve mechanical or thermal action, which inevitably causes the formation of internal stresses in the material. The severity of such phenomena depends on the chemical composition, the initial stress state of the metal, as well as a number of other characteristics. As a result, a number of difficulties arise associated with the subsequent processing of such parts, obtaining a given geometry, and known product rejects. Before using rolled metal, it uses his leveling (straightening) on roller straightening machines. The material is subjected to alternating bending (AB) at the straightening, which provides good flatness at the output. Such processing allows reducing the internal stresses of the metal, to give it the necessary plane characteristics, which greatly facilitates the subsequent processing and has a positive effect on the quality of the finished product [2]. Due to the relatively small plastic deformation in the process of straightening, the structure of the metal and its mechanical characteristics change, this 
is often not taken into account in the future. Thus, it is relevant to study the effect of alternating bending on the physical and mechanical properties of titanium and its alloys.

A limited number of works have been devoted to the study of the influence of alternating bending during the straightening of titanium sheets. It is found, for example, in [3] in the process of alternating bending of titanium sheets, a periodic change in texture from $\{11 \overline{2} 4\}\langle 11 \overline{2} 0\rangle$ to orientation $\{10 \overline{1} 4\}\langle 11 \overline{2} 0\rangle$ and vice versa, in the number and types of deformation twins in the microstructure, the formation of basic texture components It is shown that the main changes in mechanical properties and structure occur in the course of the first three to five cycles of AB. Linear correlations have been established between the averaged values of the pole density $P_{11 \overline{2} 4}$ as the most intense texture component on the inverse pole figures (IPF) of the normal direction (ND) to the rolling plane of the studied titanium sheets, on the one hand, and the averaged values of the conditional yield stress $\left(\sigma_{\mathrm{Y}}\right)$ and ultimate tensile strength $\left(\sigma_{U T S}\right)$, on the other hand, with approximation reliability coefficients of 0.83 and 0.88 , respectively. The effect of the alternating bending and crystallographic texture on the damage parameter anisotropy of industrial titanium sheets at subsequent uniaxial tensile tests was studied in [4]. Damage caused by the stresses of the yield point and ultimate strength were evaluated. It is shown that the damage parameter increases with an increase in the number of alternating bending cycles. Correlations of the anisotropy of the damage parameter and mechanical characteristics with the total value of the pole density exceeding unity at the IPF of the ND have been found. The Kearns texture parameters more objectively describe the texture of materials with a hexagonal structure [5-7]. In addition, the Kearns texture parameters make it possible to estimate the value of the physical and mechanical properties (for example, elastic) of a polycrystalline material with a hexagonal structure from the known characteristics of the corresponding single crystal [8]. The purpose of this work was to determine the parameters of the Kearns texture and evaluate, on their basis, the modulus of elasticity, mechanical properties during uniaxial tensile tests (ultimate strength, conventional yield strength), as well as parameters of damageability of sheets of commercial titanium (CT-Grade 1) titanium grade 1, as in the state of delivery after rolling and annealing at $840^{\circ}$ $\mathrm{C}$ (original sheet), and in the sheets after alternating bending $(\mathrm{AB})$ in the amount of $0.5 ; 1,3$ and 5 cycles.

\section{Material and research methods}

The material for the study was sheets of commercial titanium (CT-grade 1: $0.04 \% \mathrm{Fe} ; 0.015 \% \mathrm{C} ; 0.05 \% \mathrm{~N}$; $0.005 \% \mathrm{O} ; 0.09 \% \mathrm{H})$ as delivered after rolling and annealing at $840^{\circ} \mathrm{C}$ with a thickness of $1 \mathrm{~mm}$ (original sheet). The original sheets were cut into strips with dimensions $(100 \times 100) \mathrm{mm}$. Next, the strips were subjected to alternating bending $(\mathrm{AB})$ on a specially made device using a roller with a diameter of $50 \mathrm{~mm}$ in the rolling direction (RD). The speed of metal movement during bending was $\sim 150 \mathrm{~mm} / \mathrm{s}$. From the original sheet and from the sheets after bending for $0.5,1,3$, and 5 cycles, three parties of samples were cut out for mechanical tests in the RD, and transverse direction (TD), as well as samples to study the texture.

To study the elastic properties, rectangular specimens $100 \mathrm{~mm}$ long and $10 \mathrm{~mm}$ wide were cut out from the original sheets, as well as from sheets after $A B$, in the rolling direction and the transverse direction. Young's modulus was measured by the dynamic method from the frequency of natural bending vibrations of a flat sample [9]. The error did not exceed $1 \%$.

Mechanical tests were carried out on a tensile testing machine 250N5A WN: 143331 with a force transducer ID: $0 \mathrm{WN}$ : $80550620 \mathrm{kN}$ at room temperature for specimens cut in NP and PN. The length and width of the working part of the specimens were $15 \mathrm{~mm}$ and $12.5 \mathrm{~mm}$, respectively. The values of mechanical properties were taken as an average value over three parties of samples in each direction.

Before examining the texture, the samples were chemically polished to a depth of $0.1 \mathrm{~mm}$ to remove the distorted surface layer. The crystallographic texture was investigated from two surfaces of the samples after the above-mentioned number of $\mathrm{AB}$ cycles by recording inverse pole figures (IPF) in the normal direction (ND) to the rolling plane (ND IPF) and the direction of rolling (RD IPF) on a DRON-3m diffractometer in filtered Ka-Mo radiation. The textureless sample was made from small recrystallized sawdust of the titanium under study. Typesetting samples were made for the recording of the RD IPFs.

To characterize the damage accumulation, the socalled damage parameter $\omega$ is used, which was proposed in the early works of Kachanov [10], Rabotnov [11] and is developing in our time [12 - 14]. Damage parameter $0 \leq \omega \leq 1$ characterizes the totality of microstructural changes in the material caused by the appearance and accumulation of micro defects under operational loads. The damageability parameter is interpreted as the relative reduction in the effective, load-bearing cross-sectional area due to the accumulation of damage. Degradation of the material is explained as a gradual decrease in the effective area, which actually carries tensile loads and determines the tensile resistance of the sample.

$$
\omega=\left(S_{0}-S\right) / S_{0},
$$

where $S_{0}$ and $\mathrm{S}$ are the cross-sectional area of the intact specimen and the current cross-sectional area of the specimen, respectively; $\left(S_{0}-\mathrm{S}\right)$ - the area occupied by microvoids and microcracks.

With this interpretation, the damageability parameter can be obtained from the change in the elastic modulus. According to the hypothesis of equivalent deformation [12], the damageability parameter $\omega$ can be found from the relation:

$$
\omega_{1}=1-E / E_{0}
$$

where $E_{0}$ and $E$ are the elastic moduli of the intact specimen and the current value of the modulus, respectively.

If we use the model of equivalent elastic energy [13], then we can define $\omega$ as a tensor of the fourth rank: 


$$
\omega_{2}=1-\left(E / E_{0}\right)^{1 / 2}
$$

Only one component of the tensor in (3) is nonzero for uniaxial tension [11]. Damageability parameter $\omega$ can be found for uniaxial tension from the change in elastic characteristics, taking into account the representative volume element of orthotropic symmetry. This means that the most complex anisotropy that can be represented is orthotropic. Even with a high density of interacting cracks, the effective elastic properties remained orthotropic with good accuracy, as shown by Kachanov [10] by means of micromechanical analysis. In [15], it was experimentally shown that the assessment of the damageability parameter based on the Lemaitre equivalent deformation model [12] gives higher values of the damage parameter compared to models based on the equivalent elastic energy model [13, 14], and which give close numerical values. Therefore, the estimate of the damage parameter $\omega$ according to (3) is the best in comparison with (2) when analyzing the anisotropy of damage to sheet material [15].

\section{Experimental results and discussion}

The experimental IPFs of the alloy under study are shown in Fig. 1. In the original sheet (Fig. 1, a, b), a texture was formed, which is a combination of the recrystallization texture of the double deflected in the TD basal type $\{11 \overline{2} 4\}\langle 11 \overline{2} 0\rangle$ with scattering up to $\{10 \overline{1} 4\}\langle 10 \overline{1} 0\rangle$, which previously described, in particular, in $[3,4]$, and of annealing twins. It can be seen that all the studied titanium sheets have the texture of the double basal type deflected in the TD. However, the deflection angle and pole density change depending on the number of $\mathrm{AB}$ cycles (Fig. 1). Changes are observed in the character of texture scattering (Fig. 1c - n). The values of the pole density on the IPF also change.

To quantify the texture of hexagonal materials, Kearns texture parameters are often used [5-8]. These coefficients, $f_{j}$ (the index $j$ means the corresponding direction in the sample ND, RD, or TD), show the degree of coincidence of the $c$-axes of the crystalline hexagonal cell of grains with a given geometric direction in a polycrystalline material. They can be found from the IPF by the ratio:

$$
f_{j}=\left\langle\cos ^{2} \alpha_{i}\right\rangle_{j}=\sum_{i} A_{i} P_{j i} \cos ^{2} \alpha_{i},
$$

where $P_{j i}=\frac{I_{i} / I_{R}}{\sum_{\Delta}\left(A_{i} \cdot I_{i} / I_{R}\right)} ; I_{i} / I_{R}-$ the ratio of the integral intensity of the $i$-th reflex at the $j$-th IPF to the corresponding value of the intensity of the reflex of the sample without the texture $I_{R} ; I_{R}$ - statistical weights of the $i$-th reflex $\left(\sum A_{i} P_{j i}=1\right)$ [16]. Conventionally, $A_{i}$ is determined by the fraction of the surface area of the stereographic triangle around the normal to the $i$-th reflex of the corresponding OPF; $\alpha_{i}$ is the angle of deviation from the c axis of the $i$-th crystallographic direction for the $j$-th direction in the sample.

For hexagonal single crystals, the value of some properties of a single crystal P $(\varphi)$, connecting two vector quantities or a tensor with a scalar quantity, is determined [17] as:

$$
P(\varphi)_{r e f}=P_{c} \cos ^{2} \varphi+P_{a}\left(1-\cos ^{2} \varphi\right),
$$

where $P(\varphi)_{\text {ref }}$ is the property in the selected direction, $P_{a}$ and $P_{c}$ is the property of the single crystal in the direction perpendicular and parallel to the [0002] direction, respectively, $\varphi$ is the angle between the selected direction and [0002].

Assuming that crystallites in a polycrystalline contribute to the bulk property in proportion to their volume fraction, $\mathrm{Vi}$, the contribution to the bulk property of crystals whose axes are oriented at an angle of inclination $\varphi$ to the chosen direction can be written as:

$$
P\left(\varphi_{i}\right)_{r e f}=P_{c} V_{i} \cos ^{2} \varphi_{i}+P_{a} V_{i}\left(1-\cos \varphi_{i}\right)
$$

Summing over the entire volume, we get:

$P\left(\varphi_{i}\right)_{r e f}=P_{c} \sum_{i} V_{i} \cos ^{2} \varphi_{i}+P_{a} \sum_{i} V_{i}\left(1-\cos \varphi_{i}\right)$

Since $\sum_{i} V_{i}=1$, and $\sum_{i} V_{i} \cos ^{2} \varphi_{i}=f_{j}$ is the Kearns texture parameter, we can write:

$$
P\left(\varphi_{i}\right)_{r e f}=f_{j} P_{c}+\left(1-f_{j}\right) P_{a} .
$$

Kerns showed [8] that if a material property (such as elasticity) can be described by a tensor, then they obey the relation (8). In this case, the sum of $f_{j}$ in the three main directions of the sample should be equal to one, and a value of $1 / 3$ in each direction determines the isotropic case. Thus, if the Kearns texture coefficients found from ND IPF $\left(f_{N D}\right)$ and RD IPF $\left(f_{R D}\right)$ are known, then the Kearns coefficient for the third direction in the sheet - the transverse direction (TD) $-f_{T D}$ can be found by the ratio:

$$
f_{E D}+f_{T D}+f_{R D}=1
$$

Kerns texture parameters calculated from ND IPF $\left(f_{N D}\right)$ and RD IPF $\left(f_{R D}\right)$ from the data in Fig. 1, as well as those calculated by relation (9), are given in Table 1 .

Analysis of the distribution of pole density on the OPF of opposite sides of the sheets after a different number of $\mathrm{AB}$ cycles showed certain inconsistencies (Fig. 1, c, d; f, $\mathrm{g} ; \mathrm{i}, \mathrm{j} ; \mathrm{l}, \mathrm{m})$. The noted inconsistencies in the distribution of pole density on the ND OPF after a different number of $\mathrm{AB}$ cycles are reflected in the value of the Kearns texture parameters calculated from the ND OPF of the opposite sides of the sheets after the $\mathrm{AB}$.

The cause of this discrepancy is that when bending to one side, the metal layers on the convex side of the sheet are subjected to tensile deformation. At the same time, the corresponding metal layers on the concave side of the sheet are deformed by compression. The deformation processes are reversed when the bending 

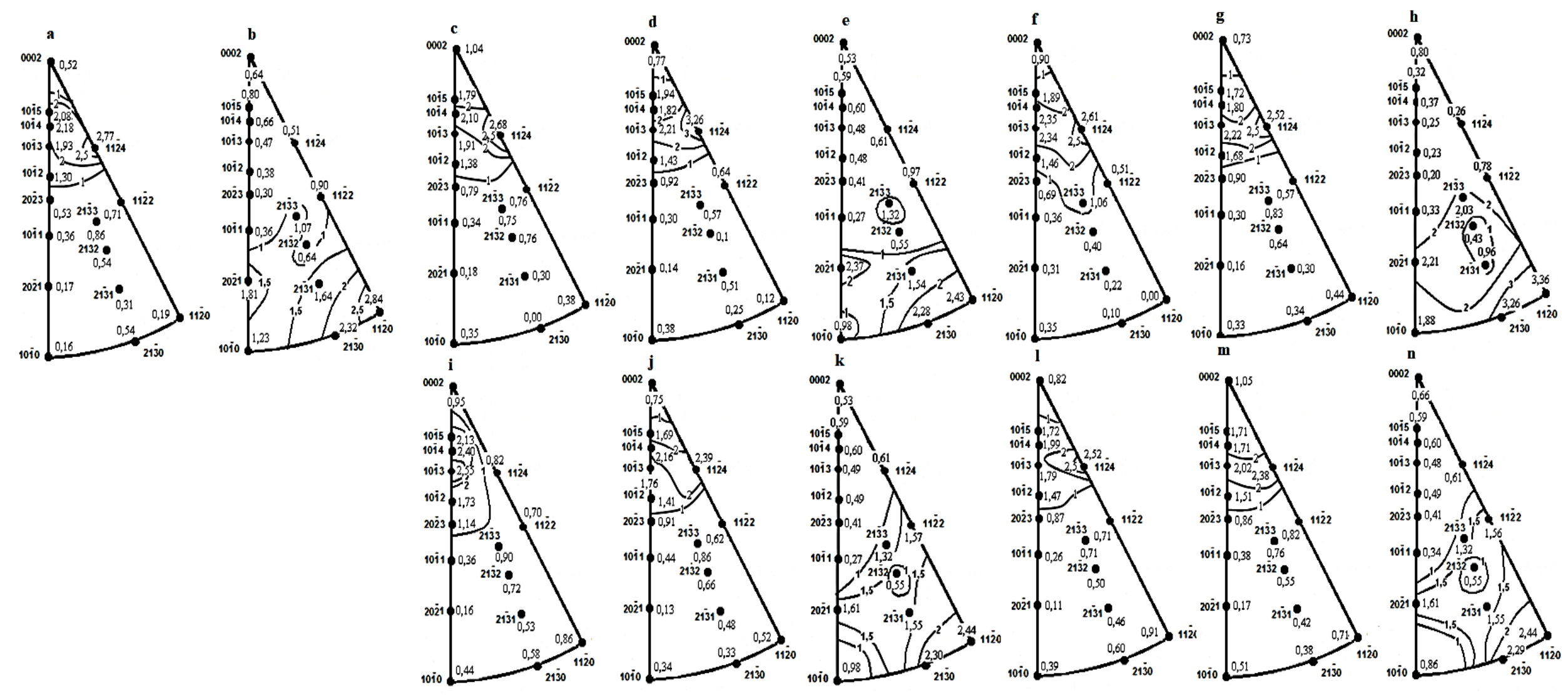

Fig. 1. Experimental inverse pole figures of titanium: (a, b) - original sheet; sheets after reverse bending by 0.5 (c - e); 1 - (f-h); 3 - (i-k); 5 - (l-n) cycles; (b, e, h, k, n) corresponds to the rolling direction (RD); (a, c, d, f, g, i, j, l, m) corresponds to the normal direction (ND) to the rolling plane; $(\mathrm{c}, \mathrm{f}, \mathrm{i}, \mathrm{l})$ - the stretched side of the sheets; $(\mathrm{d}, \mathrm{g}, \mathrm{j}, \mathrm{m})$ - the compressed side of the sheets. 
sign changes. Similar inconsistencies in the distribution of pole density on the IPF of the outer and inner sides of the strips obtained after cutting along the axis tube made of $\mathrm{Zr}-2.5 \% \mathrm{Nb}$ alloy and straightening were found earlier in [19]. For further analysis of the influence of alternating bending on the properties of the studied alloy in the ND, we used the values of the Kearns texture parameters $f_{N D}$ averaged over both sides of the sheets $f_{N D}^{(a v)}$ after the corresponding number of $\mathrm{AB}$ cycles.

The values of the studied titanium sheets elasticity modulus measured and calculated at the ND, RD, and TD according to relations of the type (8) are presented in Table 2. We used at the calculations the values of elastic modulus of a single crystal of titanium [20], a close chemical composition. According to [20] the elastic modulus along the hexagonal $c$ axis $\left(E_{c}=130 \mathrm{GPa}\right)$, and along the $a$-axis $\left(E_{a}=99 \mathrm{GPa}\right)$.

It is seen that the maximum deviation of the calculated and experimental values of the elastic modulus does not exceed $5 \%$. It was not possible to measure the modulus of elasticity in NN due to the small thickness of the sheets (1 $\mathrm{mm})$.

Analysis of the experimental values of the elastic modulus of sheets shows that with an increase in the number of $\mathrm{AB}$ cycles, the value of the elastic modulus decreases. This is due to the accumulation of microscopic damage with an increase in the degree of deformation (the number of $\mathrm{AB}$ cycles), which leads to a decrease in the effective cross-sectional area of the samples and an increase in the damage coefficient in accordance with relations (1) - (3). The results of assessing the damage parameters based on the hypothesis of equivalent deformation [12] according to relation (2), and on the basis of the equivalent elastic energy model [13] (3) are presented in Table. 3.

As can be seen (Table 3), the values of $\omega_{1}$ and $\omega_{2}$ in the TD in the course of the $\mathrm{AB}$ are greater than their values in the RD of sheets. In addition, with an increase in the number of $\mathrm{AB}$ cycles to 5, the values of $\omega_{1}$ and $\omega_{2}$ of the samples of the studied titanium in RD increase, while the values $\omega_{1}$ and $\omega_{2}$ in the TD of sheets increase with an increase in the number of $\mathrm{AB}$ cycles to 3 , and after 5 cycles of the AB they decrease.

Let us estimate the ultimate strength $\sigma_{U T S}$ and yield strength $\sigma_{\mathrm{Y}}$ of sheets of the studied titanium according to the data for a single crystal. For this purpose, let us first estimate the ultimate strength and yield strength of the titanium single crystal of the commercial titanium (CP grade 1) under study along the $c$ axis $\left(\sigma_{U T S}^{c}\right.$ and $\sigma_{Y}^{c}$, respectively) and along the $a$ axis $\left(\sigma_{U T S}^{a}\right.$ and $\left.\sigma_{\mathrm{Y}}^{a}\right)$. There

Table 1

Kerns texture options

\begin{tabular}{|c|c|c|c|c|c|}
\hline \multirow{2}{*}{ Cycle's number, $\mathrm{n}$} & \multicolumn{5}{|c|}{ Kerns texture options } \\
\cline { 2 - 6 } & $f_{N D}^{(1)}$ & $f_{N D}^{(2)}$ & $f_{N D}^{(a v)}$ & $f_{R D}$ & $f_{T D}$ \\
\hline 0 & 0.593 & 0.593 & 0.593 & 0.236 & 0.171 \\
\hline 0.5 & 0.549 & 0.573 & 561 & 0.240 & 0.474 \\
\hline 1.0 & 0.573 & 0.541 & 0.557 & 0.249 & 0.194 \\
\hline 3.0 & 0.512 & 0.523 & 0.518 & 0.248 & 0.234 \\
\hline 5.0 & 0.528 & 0.522 & 0.525 & 0.248 & 0.227 \\
\hline
\end{tabular}

Table 2

Calculated and experimental values of the elastic modulus titanium of grade 1

\begin{tabular}{|c|c|c|c|c|c|c|c|c|}
\hline $\begin{array}{c}\text { Number } \\
\text { cycles, N }\end{array}$ & $\begin{array}{c}E_{N D}^{\text {calc. }} \\
\mathrm{GPa}\end{array}$ & $\begin{array}{c}E_{N D}^{\text {exp. }} \\
\mathrm{GPa}\end{array}$ & $\begin{array}{c}E_{R D}^{\text {calc. }}, \\
\mathrm{GPa}\end{array}$ & $\begin{array}{c}E_{R D}^{\text {exp. }} \\
\mathrm{GPa}\end{array}$ & $\begin{array}{c}\Delta E_{E_{\text {exp. }},} \\
\%\end{array}$ & $\begin{array}{c}E_{T D}^{\text {calc. }} \\
\mathrm{GPa}\end{array}$ & $\begin{array}{c}E_{R D}^{\text {exp. }}, \\
\mathrm{GPa}\end{array}$ & $\begin{array}{c}\Delta E / E_{\text {exp. }}, \\
\%\end{array}$ \\
\hline 0 & 117.383 & - & 106.316 & 107.6 & 1.19 & 104.301 & 104.8 & -0.5 \\
\hline 0.5 & 116.391 & - & 106.440 & 107.4 & 0.89 & 105.169 & 104.0 & 1.1 \\
\hline 1.0 & 116.267 & - & 106.719 & 106.4 & -0.30 & 105.014 & 103.6 & 1.7 \\
\hline 3.0 & 115.058 & - & 106.688 & 106.0 & -0.65 & 106.254 & 102.5 & 3.7 \\
\hline 5.0 & 115.275 & - & 106.688 & 105.4 & -1.22 & 106.037 & 103.0 & 3.0 \\
\hline
\end{tabular}

Table 3

Dependence of the damage coefficient $\omega$ on the number of $\mathrm{AB}$ cycles

$\left.\begin{array}{|c|c|c|c|c|}\hline \begin{array}{c}\text { Cycle's } \\ \text { number, } \mathrm{n}\end{array} & \begin{array}{c}\omega_{1}=1-E / E_{0}, \\ \%\end{array} & \begin{array}{c}\omega_{2}=1-\left(E / E_{0}\right)^{0.5}, \% \\ \mathrm{RD}\end{array} & \begin{array}{c}\omega_{1}=1-E / E_{0}, \% \\ \mathrm{TD}\end{array} & \omega_{2}=1-\left(E / E_{0}\right)^{0.5}, \% \\ \mathrm{TD}\end{array}\right)$


Ultimate strengths $\sigma_{U T S}$ measured and calculated using the parameters of the Kearns texture (Table 1) and the values of $\sigma_{U T S}^{c}$ and $\sigma_{U T S}^{a}$ a of a titanium single crystal (12), (13)

\begin{tabular}{|c|c|c|c|c|c|c|c|c|}
\hline $\begin{array}{l}\text { Number } \\
\text { cycles, } \mathrm{N}\end{array}$ & $\begin{array}{c}\sigma_{U T S \text { calc }}^{N D} \\
\mathrm{MPa}\end{array}$ & $\begin{array}{c}\sigma_{U T S \text { exp }}^{N D}, \\
\text { MPa }\end{array}$ & $\begin{array}{c}\sigma_{U T S \text { calc }}^{R D} \\
\mathrm{MPa}\end{array}$ & $\begin{array}{c}\sigma_{U T S}^{R D} \text { exp } \\
\mathrm{MPa}\end{array}$ & $\begin{array}{c}\Delta \sigma / \sigma_{\text {exp }} \\
\%\end{array}$ & $\begin{array}{c}\sigma_{U T S \text { calc }}^{T D} \\
\mathrm{MPa}\end{array}$ & $\begin{array}{c}\sigma_{U T S \text { exp }}^{T D} \\
\mathrm{MPa}\end{array}$ & $\begin{array}{c}\Delta \sigma / \sigma_{\text {exp }} \\
\%\end{array}$ \\
\hline 0 & 380.3 & - & 386.0 & 365.0 & 5.8 & 387.0 & 365.0 & 6.0 \\
\hline 0.5 & 380.8 & - & 385.9 & 372.0 & 3.7 & 386.6 & 380.0 & 1.7 \\
\hline 1.0 & 380.9 & - & 385.8 & 365.0 & 5.7 & 386.7 & 382.0 & 1.2 \\
\hline 3.0 & 381.5 & - & 385.8 & 375.0 & 2.9 & 386.0 & 391.0 & -1.3 \\
\hline 5.0 & 381.4 & - & 385.8 & 370.0 & 4.3 & 386.2 & 385.0 & 0.3 \\
\hline
\end{tabular}

Table 5

Yield strengths $\sigma_{Y}$ measured and calculated using Kerns texture parameters (Table 1) and the values of $\sigma_{Y}^{c}$ и $\sigma_{Y}^{a}$ of the titanium single crystal (12), (13)

\begin{tabular}{|c|c|c|c|c|c|c|c|c|}
\hline $\begin{array}{c}\text { Number } \\
\text { cycles, } \mathrm{N}\end{array}$ & $\begin{array}{c}\sigma_{Y \text { calc, }}^{N D} \\
\mathrm{MPa}\end{array}$ & $\begin{array}{c}\sigma_{Y}^{N D} \text { exp, } \\
\mathrm{MPa}\end{array}$ & $\begin{array}{c}\sigma_{Y \text { calc }}^{R D}, \\
\mathrm{MPa}\end{array}$ & $\begin{array}{c}\sigma_{Y}^{R D} \text { exp }, \\
\mathrm{MPa}\end{array}$ & $\begin{array}{c}\Delta \sigma / \sigma_{\text {exp. }}, \\
\%\end{array}$ & $\begin{array}{c}\sigma_{Y}^{T D} \text { calc, } \\
\mathrm{MPa}\end{array}$ & $\begin{array}{c}\sigma_{Y}^{T D} \text { exp, }, \\
\mathrm{MPa}\end{array}$ & $\begin{array}{c}\Delta \sigma / \sigma_{\text {exp. }}, \\
\%\end{array}$ \\
\hline 0 & 320. & - & 325.7 & 300.0 & 8.6 & 326.5 & 305.0 & 7.1 \\
\hline 0.5 & 321.3 & - & 325.6 & 297.0 & 9.6 & 326.2 & 300.0 & 8.7 \\
\hline 1.0 & 321.3 & - & 325.5 & 300.0 & 8.5 & 326.2 & 310.0 & 5.2 \\
\hline 3.0 & 321.9 & - & 325.5 & 310.0 & 5.0 & 325.7 & 336.0 & -3.1 \\
\hline 5.0 & 321.8 & - & 325.5 & 320.0 & 1.7 & 325.8 & 340.0 & -4.2 \\
\hline
\end{tabular}

are no such data in the literature. However, they can be found using hardness data from nanoindentation results. These results differ significantly depending on the titanium purity. Thus, for titanium of high purity (iodide titanium, HP Ti, CP Ti (grade 1)), the minimum value of hardness was found upon nanoindentation of the basal plane $[21,22]$. At the same time, in titanium of lower purity, as, for example, in commercial titanium $\mathrm{CP} \mathrm{Ti}$ (grade 2), the basal plane is the hardest [23-25]. In [22], experimental results of measuring the Vickers hardness $\left(H_{V}\right)$ along the hexagonal axis $\left(H_{V}^{c}=1770 \mathrm{MPa}\right)$ and across it $\left(H_{V}^{a}=1220 \mathrm{MPa}\right)$ are presented in single crystals of pure titanium, which chemical composition is close in to the one studied by us in this work. We estimate the values of the corresponding ultimate strength $\sigma_{U T S}^{c}$ and yield strength $\sigma_{\mathrm{Y}}^{a}$ using empirical relations [26], which have the form:

$$
\begin{gathered}
\sigma_{U T S}=\frac{H_{V}}{2.9} \cdot(1-n) \cdot\left[\frac{12.5 \cdot n}{1-n}\right]^{n}, \\
\sigma_{Y}=\frac{H_{V}}{3} \cdot(0.1)^{n},
\end{gathered}
$$

where $n$ is the hardening parameter equal to 0.11 for titanium according to the data of [26].

Using relations (10) and (11), as well as the values $H_{V}^{c}=1170 \mathrm{MPa}$ and $H_{V}^{a}=1220 \mathrm{MPa}$, we obtain:

$$
\begin{gathered}
\sigma_{U T S}^{c}=374 \mathrm{MПа,} \sigma_{\mathrm{Y}}^{c}=315 \mathrm{MПа} \\
\sigma_{U T S}^{a}=356 \mathrm{MПа.} \sigma_{\mathrm{Y}}^{a}=329 \mathrm{MПа.}
\end{gathered}
$$

To estimate the ultimate strength of the titanium under study, we use relationships similar to (8):

$$
\begin{aligned}
& \sigma_{U T S}^{N D}=f_{E D} \cdot \sigma_{U T S}^{c}+\left(1-f_{E D}\right) \cdot \sigma_{U T S}^{a} \\
& \sigma_{U T S}^{T D}=f_{T D} \cdot \sigma_{U T S}^{c}+\left(1-f_{T D}\right) \cdot \sigma_{U T S}^{a} \\
& \sigma_{U T S}^{R D}=f_{R D} \cdot \sigma_{U T S}^{c}+\left(1-f_{R D}\right) \cdot \sigma_{U T S}^{a}
\end{aligned}
$$

Similarly for the yield points, we get:

$$
\begin{aligned}
& \sigma_{\mathrm{Y}}^{N D}=f_{E D} \cdot \sigma_{\mathrm{Y}}^{c}+\left(1-f_{E D}\right) \cdot \sigma_{Y}^{a} \\
& \sigma_{0,2}^{T D}=f_{T D} \cdot \sigma_{Y}^{c}+\left(1-f_{T D}\right) \cdot \sigma_{Y}^{a} \\
& \sigma_{B}^{R D}=f_{R D} \cdot \sigma_{\mathrm{Y}}^{c}+\left(1-f_{R D}\right) \cdot \sigma_{Y}^{a}
\end{aligned}
$$

The results of calculations and measurements of ultimate strength are presented in Table 4.

The results of calculations and measurements of the yield strength are presented in Table 5.

As can be seen from Tables 4, 5, the maximum deviation of the strength and yield strength values measured in RD and TD of the sheets of the studied titanium and calculated using the Kerns texture parameters does not exceed $10 \%$. It is not possible to measure the aforementioned strength characteristics in $\mathrm{DN}$ of the titanium sheets under study due to their small thickness (1 $\mathrm{mm})$.

\section{Conclusion}

The Kearns texture parameters were found, and on their basis the elasticity moduli and mechanical properties were estimated during uniaxial tensile tests (ultimate 
strength, conditional yield point) of grade 1 titanium sheets $(0.04 \% \mathrm{Fe} ; 0.015 \% \mathrm{C} ; 0.05 \% \mathrm{~N} ; 0.005 \% \mathrm{O}$; $0.09 \% \mathrm{H})$ as delivered after rolling and annealing at $840{ }^{\circ} \mathrm{C}$ (original sheet) and further alternating bending (AB) in the amount of $0.5 ; 1.0,3.0$ and 5.0 cycles.

The Kearns texture parameters, which show the degree of coincidence of the hexagonal axis of the crystal cell of grains with a given geometric direction in a polycrystalline sample, were calculated from the inverse pole figures of the normal direction to the sheet plane and inverse pole figures of the rolling direction.

The elastic constants of a single crystal of commercial titanium (CT Grade 1) and the calculated parameters of the Cairns texture were used to estimate the elastic modulus in the direction of rolling in the transverse direction of the original sheet, as well as after above number cycles of alternating bending. The calculated values of the modulus of elasticity deviated from the corresponding measured values within $5 \%$.

Damageability parameters characterizing damage accumulation were determined from the change in the elastic modulus after the specified number of alternating bending cycles relative to the values of the elastic modulus in different directions of the original sheet of the alloy under study. Damageability parameters were calculated using equivalent deformation and equivalent elastic energy models. It was found that the damageability parameters in the transverse direction in the process of alternating bending are greater than in the direction of sheet rolling. In addition, with an increase in the number of cycles of alternating bending to 5, the parameters of the damageability of the samples of the studied titanium in the direction of rolling increase, at the same time, the damageability parameters of in the transverse direction of letters increase with an increase in the number of cycles of alternating bending to three, and after five cycles of alternating bending, they decrease.

On the basis of empirical relationships between hardness and strength, the values of the ultimate strength and yield strength of a titanium single crystal were found along its hexagonal axis and perpendicular to it. The tensile strength and yield strength of the studied polycrystalline titanium sheets, both in the initial state and after the corresponding number of alternating bending cycles, were estimated in the rolling and transverse directions using the above ultimate strength and yield strength of a titanium single crystal and Kearns texture parameters. The deviation from the corresponding experimental values did not exceed $10 \%$.

The methods described above for assessing the physical and mechanical properties of the polycrystalline materials with a hexagonal structure can be used in cases where it is difficult or impossible to measure the property in a certain direction of a polycrystalline sample. For example, in the direction normal to the plane of thin sheets, or after wire drawing, as well as after screw extrusion of the sample, perpendicular to their axis.

Usov V.V. - Professor, Doctor of physical and mathematical science, Professor of the department of technological and vocational education;

Shkatulyak N.M. - Ph.D., Dozent, Dozent of the Physics department;

Savchuk O.S. - Ph.D, lecturer of the Physics and Chemistry department;

Rybak N.I. - a graduate student of the Physics department.

[1] A. Khorev, Heat, thermo-mechanical treatment and textural hardening of welded titanium alloys; https://www.viam.ru/public/files/2012/2012-206018.pdf [in Russian].

[2] Methods of leveling sheet metal; https://blog.arku.com/us/methods-of-leveling-sheet-metal/.

[3] В. Усов, П. Брюханов, М. Родман, Н. Шкатуляк, М. Шапер, Х. Клозе, Ф.-В. Бах, Деформация и разрушение материалов 9, 33 (2012); http://www.nait.ru/journals/number.php?p_number_id=1692.

[4] N. Shkatulyak, E. Savchuk, V. Usov, Journal of Materials Research and Technology 7(1), 82 (2017); https://doi.org/10.1016/j.jmrt.2017.06.007.

[5] J. Kearns, Thermal Expansion and Preferred Orientation in Zircaloy; https://ntrl.ntis.gov/NTRL/dashboard/searchResults/titleDetail/WAPDTM472.xhtml.

[6] D. Dzunovich,, S. Betsofen, and P. Panin, Russian Metallurgy (Metally) 10, $813 \quad$ (2017); https://doi.org/10.1134/S0036029517100056.

[7] V. Grytsyna, D. Malykhin, T. Yurkova et al., East Eur. J. Phys. 3, 38 (2019); https://doi.org/10.26565/23124334-2019-3-05.

[8] J. Kearns, Journal of Nuclear Materials 299(2), 171 (2001); https://doi.org/10.1016/S0022-3115(01)00686-9.

[9] Standard Test Method for Dynamic Young's Modulus, Shear Modulus, and Poisson's Ratio by Impuls Excitation of Vibration; http://forlab.pt/wp-content/uploads/2015/08/E1876_mvuj8965.pdf.

[10] L.M. Kachanov, Fundamentals of fracture mechanics (Nauka, Moscow, 1974) [in Russian].

[11] Y.N. Rabotnov, Selected works. Problems of Solid Mechanics (Nauka, Moscow, 1991) [in Russian].

[12] J. Lemaitre, R. Desmorat, Eur. J. Mech. A /Solids/ 19(2), 187 (2000); https://doi.org/10.1016/s09977538(00)00161-3.

[13] N. Hansen, H. Schreyer, Int. J. Solid. Structures 31(3), 359 (1994); https://doi.org/10.1016/00207683(94)90112-0.

[14] C. Chow, J. Wang, International Journal of Fracture 33(1), 3 (1987); https://doi.org/10.1007/BF00034895.

[15] M. Bobyr, O. Khalimon, O. Bondarets, Journal of Mechanical Engineering NTUU «Kyiv Polytechnic Institute» 67, 5 (2013); http://nbuv.gov.ua/UJRN/VKPI_mash $2013 \quad 67 \quad 3$.

[16] P.R. Morris, Journal of Applied Physics 30(4) (1959); https://doi.org/10.1063/1.1702413. 
[17] J.F. Nye, Physical properties of crystals their representation. Their representation by tensors and matrices, (Oxford: University Press, 2006).

[18] Ya.D. Vishnyakov, A.A. Babareko, S.A. Vladimirov, I.V. Egiz, The theory of texture formation in metals and alloys (Nauka, Moscow, 1979 [in Russian].

[19] V. Grytsyna, D. Malykhin, T. Yurkova et al., East. Eur. J. Phys. 3, 38 (2019); https://doi.org/10.26565/23124334-2019-3-05.

[20] J. Gong \& A. Wilkinson, Philosophical Magazine Letters 90(7), $503 \quad$ (2010); https://doi.org/10.1080/09500831003772989.

[21] F.K. Mante, G.R. Baran, B. Lucas, Biomaterial 20, 1051 (1999); https://doi.org/10.1016/S0142-9612(98)002579.

[22] S.V. Lubenets, A.V. Rusakova, L.S. Fomenko, and V.A. Moskalenko, Low Temp. Phys. 44(1), 73 (2018); https://doi.org/10.1063/1.5020901.

[23] E. Merson, R. Brydson, and A. Brown, Journal of Physics, Conference Series 126, 012020 (2008); https://doi.org/10.1088/1742-6596/126/1/012020.

[24] C. Zambaldi, Y. Yang, T. R. Bieler, D. Raabe, J. Mater. Res., 27(1), 356 (2012); https://doi.org/10.1088/17426596/126/1/012020.

[25] M.W. Priddy, D.L. McDowell, S.R. Kalidindi, $\quad$ Acta $\quad$ Materialia $117, \quad 23 \quad$ (2016); https://doi.org/10.1016/j.actamat.2016.06.053.

[26] F. Khodabakhshi, M. Haghshenas, H. Eskandari, B., Materials Science \& Engineering A 636(11), 331 (2015); https://doi.org/10.1016/j.msea.2015.03.122.

\title{
В.В. Усов르, Н.М. Шкатуляк ${ }^{1}$, О.С. Савчук ${ }^{2}$, Н.І. Рибак ${ }^{1}$ \\ Параметри текстури Кернса, механічні властивості та пошкоджуваність титанових листів після знакозмінного вигину
}

\author{
${ }^{1}$ Південноукраӥнський наџіональний педагогічний університет імені К.Д. Уиинського, Одеса, Украйна, \\ valentinusov67@gmail.com \\ ${ }^{2}$ Національний університет «Одеська морська академія», Одеса, Україна; z9816@уапdех.иа
}

\begin{abstract}
Метою даної роботи є визначення параметрів текстури Кернса і оцінка на їх основі модулів пружності, механічних властивостей при випробуваннях на одновісний розтяг (межа міцності, умовна межа плинності), а також параметрів пошкоджуваності листів титану марки 1 (0,04\% Fe; 0,015 \% C; 0,05\% N $0,05 \%$ в; $0,009 \%$ Н) в стані поставки після вальцювання і відпалу при $840^{\circ} \mathrm{C}$ (вихідний лист) і подальшого знакозмінного вигину (3В) в кількості 0,5; 1,3 і 5 циклів. Параметри пошкоджуваності, що характеризують накопичення пошкоджень, визначали зі зміні модуля пружності після вищезазначеного числа циклів ЗВ відносно значень модуля пружності в різних напрямках вихідного листа досліджуваного сплаву. Константи пружності монокристалів і розраховані параметри текстури Кернса використано для оцінки модуля пружності в напрямку вальцювання (НB) і поперечному напрямку (ПН) вихідного листи, а також листів після зазначеного вище числа циклів 3В. Відхилення розрахункових й експериментальних значень модуля пружності не перевищило 5 \%. Відхилення розрахункових і експериментальних значень межі міцності і межі текучості досліджуваних листів полікристалічного титану в НВ і ПН, як в початковому стані, так і після відповідної кількості циклів ЗВ не перевищували $10 \%$.

Ключові слова: параметри текстури Кернса, модуль пружності, межа міцності, умовна межа плинності, параметр пошкоджуваності.
\end{abstract}

